\title{
HUBUNGAN KOMUNIKASI INTERPERSONAL MAHASISWA DENGAN DOSEN DAN ANTAR MAHASISWA DENGAN MOTIVASI BELAJAR
}

\author{
Prasetyo Catur Utomo, Ari Probandari, Nunuk Suryani \\ Politeknik Kesehatan Surakarta Jurusan Ortotik Prostetik \\ Magister Kedokteran Keluarga Program Pascasarjana UNS
}

\begin{abstract}
Interpersonal Communication, Learning Motivation. Interpersonal communication between students and lecturers and among students suspected to be a factor that will contribute to increase learning motivation. The purpose of this study, to measure the relationship of interpersonal communication between students and lecturer and among students with learning motivation at Prosthetic Orthotic Department of Health Polytechnic Surakarta. This study was descriptive analytic research with cross sectional approach. The population of this study were all students of Prosthetic Orthotic Department of Health Polytechnic Surakarta. 234 students. The sample were 150 students. The technique to choose the sample used simple random sampling. The technique to collect data used interpersonal communication questionnaires and learning motivation questionnaire. Data were analyzed using multiple linear regression analysis. There is statistically positive and significant correlation between interpersonal communication between students and lecturers and among students with learning motivation $(r=0.510)$. The impact amount of interpersonal communication between students and lecturers and among students with learning motivation is $26 \%\left(r^{2}=\right.$ 0.260). Interpersonal communication between students and lecturers and among students has correlation with learning motivation.
\end{abstract}

Keywords: Interpersonal Communication, Learning Motivation

Abstrak: Komunikasi Interpersonal, Motivasi Belajar. Komunikasi interpersonal baik antar mahasiswa ataupun antara mahasiswa dengan dosen diduga merupakan sebuah faktor yang akan turut berpersan terhadap peningkatan motivasi belajar mahasiswa. Tujuan dari penelitian ini adalah untuk mengukur hubungan antara komunikasi interpersonal mahasiswa dengan dosen dan antar mahasiswa terhadap motivasi belajar di Jurusan Ortotik Prostetik Poltekkes Kemenkes Surakarta. Jenis penelitian ini merupakan penelitian deskriptif analitik dengan pendekatan cros sectional. Populasi dari penelitian ini adalah seluruh mahasiswa Jurusan Ortotik Prostetik Poltekkes Kemenkes Surakarta, yang berjumlah 234 mahasiswa. Jumlah sampel adalah 150 mahasiswa. Teknik pengumpulan data menggunakan kuesioner komunikasi interpersonal dan kuesioner motivasi belajar. Teknik analisis data menggunakan analisis regresi liner berganda. Terdapat hubungan yang positif dan signifikan secara statistik antara komunikasi interpersonal mahasiswa dengan dosen dan antar mahasiswa terhadap motivasi belajar $(r=0,510)$. Besarnya pengaruh komunikasi interpersonal mahasiswa dengan dosen dan antar mahasiswa terhadap motivasi belajar adalah $26 \%\left(\mathrm{r}^{2}=0,260\right)$.

Kata Kunci : Komunikasi Interpersonal, Motivasi Belajar 


\section{PENDAHULUAN}

Motivasi belajar mahasiswa dapat didefinisikan sebagai suatu keadaan dalam diri mahasiswa yang mendorong dan mengarahkan perilakunya kepada tujuan yang ingin dicapainya dalam mengikuti pendidikan tinggi (Sardiman, 2011). Salah satu faktor eksternal yang mempengaruhi motivasi belajar seseorang adalah kondisi lingkungan mahasiswa, antara lain dosen dengan segala aspek yang dimilikinya termasuk metode pembelajaran, penggunaan model-model pembelajaran yang tepat, kemampuan pengelolaan kelas, kemampuan berkomunikasi secara interpersonal dengan mahasiswa, media, kurikulum perguruan tinggi, sarana dan prasarana belajar dan tata tertib serta kedisiplinan Uno (2010).

Komunikasi interpersonal atau komunikasi antarpribadi adalah proses penyampaian dan penerimaan pesan antara pengirim pesan (sender) dengan penerima (receiver) baik secara langsung maupun tidak langsung (Suranto, 2011). Komunikasi interpersonal adalah proses pertukaran informasi diantara seseorang dengan paling kurang seorang lainnya atau biasanya di antara dua orang yang dapat langsung diketahui balikannya (Muhammad, 2005).

Hubungan mahasiswa dengan dosen di dalam proses belajar mengajar merupakan faktor yang sangat penting dalam menciptakan suasana belajar yang menyenangkan sehingga mahasiswa ingin belajar dan dosen nyaman dalam mengajar. Ada fenomena yang menarik di Jurusan Ortotik Prostetik tentang permasalahan komunikasi interpersonal dan motivitasi belajar. Ada kecenderungan bahwa mahasiswa yang mampu berkomunikasi interpersonal secara bagus, baik dengan dosen maupun dengan mahasiswa lain, cenderung memiliki motivasi belajar yang baik pula. Begitu pula sebaliknya. Berdasarkan hal yang telah diuraikan diatas, maka tujauan dari penelitian ini adalah untuk mengetahui dan mengukur hubungan antara komunikasi interpersonal mahasiswa dengan dosen dan antar mahasiswa terhadap motivasi belajar di jurusan Ortotik Prostetik Poltekkes Surakarta.

\section{METODE PENELITIAN}

Subjek dalam penelitian ini adalah 150 orang mahasiswa Jurusan Ortotik Prostetik Poltekkes Kemenkes Surakarta, baik pria maupun wanita.

Teknik pengumpulan data yang digunakan dalam penelitian ini adalah dengan metode kuesioner. Kuesioner penelitian terdiri atas skala komunikasi interpersonal mahasiswa dengan dosen, kuesioner komunikasi interpersonal antar mahasiswa dan kuesioner motivasi belajar.

Sebelum digunakan dalam penelitian, terlebih dahulu dilakukan uji coba. Uji coba dilakukan untuk mengetahui indeks daya beda aitem masing-masing skala dan keterpercaan alat ukutnya. Azwar (2003) menyatakan bahwa uji coba terhadap aitem bertujuan untuk mengetahui apakah kalimat dalam aitem mudah dan dapat dipahami oleh responden sebagaimana yang diinginkan oleh penulis aitem.

Ketiga skala diuji cobakan secara bersama-sama kepada subjek yang memiliki karakteristik yang sama dengan subjek penelitian. Uji coba dilakukan dengan sampel uji coba berjumlah 35 mahasiswa Jurusan ortotik prostetik Poltekkes Surakarta. Setelah dilakukan uji coba alat ukur, maka aitem yang valid dan 
yang gugur dapat ditentukan dengan bantuan program statistical packages for social science (SPSS) versi 18.0. Batas daya beda aitem yang digunakan pada skala yang digunakan berdasarkan kesepakatan umum para ahli yaitu rix $\geq$ 0,30 . Menurut azwar (2003) aitem yang mencapai koefisien korelasi minimal 0,3 dipandang memiliki daya beda yang memuaskan. Oleh karena itu dalam penelitian ini menggunakan standar minimal rix $=0,30$ untuk memilih aitem yang memiliki daya beda tinggi.

Setelah dilakukan uji validitas dan reliabilitas, maka pada skala komunikasi interpersonal mahasiswa dengan dosen terdapat 27 aitem valid dan 13 aitem dinyatakan gugur. Skala komunikasi interpersonal antar mahasiswa terdapat 19 aitem valid dan 21 aitem dinyatakan gugur. Skala motivasi belajar terdapat 23 aitem valid dan 9 aitem dinyatakan gugur.

\section{HASIL PENELITIAN}

Berdasarkan analisis data yang dilakukan dengan menggunakan teknik analisis regresi linier berganda pada program SPSS versi 18.0, diketahui bahwa nilai koefisien korelai $\mathrm{R}=0,510$ dengan nila sig. $F$ change $=0,000$.

Tabel 1

\section{Hasil Uji Regresi Linier Berganda}

\begin{tabular}{|c|c|c|c|}
\hline \multirow[t]{2}{*}{ Variabel } & \multirow{2}{*}{$\begin{array}{c}\text { Koefisien } \\
\text { Regresi }\end{array}$} & $\begin{array}{c}\text { Confidence } \\
\text { Interval } \\
95 \% \\
\end{array}$ & Sig. \\
\hline & & $\begin{array}{c}\text { Batas } \\
\text { bawah }\end{array}$ & $\begin{array}{l}\text { Batas } \\
\text { atas }\end{array}$ \\
\hline Konstanta & 26,703 & 13,391 & 40,015 \\
\hline $\begin{array}{l}\text { Komunikasi } \\
\text { Interpersonal } \\
\text { Mahasiswa dengan } \\
\text { dosen }\end{array}$ & 0,265 & 0,16 & 0,415 \\
\hline $\begin{array}{l}\text { Komunikasi } \\
\text { Interpersonal } \\
\text { Antar mahasiswa }\end{array}$ & 0,414 & 0,197 & 0,632 \\
\hline $\begin{array}{l}F_{\text {hitung }}=25,862 \\
\text { Sig.F change }= \\
0,000\end{array}$ & $\begin{array}{l}\mathrm{R}= \\
0,510 \\
\mathrm{R}^{2}= \\
0,260\end{array}$ & & \\
\hline
\end{tabular}

Berdasarkan hasil tersebut, maka hipotesis yang berbunyi "ada hubungan antara variabel komunikasi interpersonal mahasiswa dengan dosen dan antar mahasiswa terhadap motivasi belajar" diterima.

\section{PEMBAHASAN}

Berdasarkan penelitian yang telah dilakukan, maka dapat disimpulkan hasil yang telah diperoleh dalam penelitian ini adalah sebagai berikut, terdapat hubungan yang positif dan signifikan antara komunikasi interpersonal mahasiswa dengan dosen dan antar mahasiswa terhadap motivasi belajar mahasiswa di Jurusan ortotik prostetik Poltekkes Kemenkes Surakarta dengan $\mathrm{R}=0,510$ dan sig. $\mathrm{f}$ change $=0,000$ (sig.F change < 0,05). Angka ini menunjukkan semakin baik komunikasi mahasiswa dengan dosen dan antar mahasiswa, maka akan semakin tinggi motivasi belajarnya.

\section{KESIMPULAN DAN SARAN}

Hipotesis pada penelitian ini diterima. Besarnya pengaruh komunikasi interpersonal mahasiswa dengan dosen dan antar mahasiswa terhadap motivasi belajar adalah 26\%, sedangkan $74 \%$ ditentukan oleh faktor-faktor lain yang tidak diungkap dalam penelitian ini.

Beberapa saran yang dapat dikemukakan dari hasil penelitian ini adalah sebagai berikut :

1. Bagi subjek

a. Disarankan ketika proses perkuliahan, sering melakukan diskusi tentang permasalahan atau kasus-kasus yang sedang dihadapi saat proses belajar mengajar. Mahasiswa harus lebih mampu terbuka, memiliki empati dan mampu menempatkan diri ketika 
berkomunikasi dengan mahasiswa lain.

b. Mahasiswa juga disarankan agar tidak merasa canggung untuk bertanya tentang materi-materi perkuliahan yang dirasa belum dipahami. Dalam proses belajar mengajar mahasiswa dituntut untuk aktif dalam diskusi dengan dosen.

2. Bagi Jurusan Ortotik Prostetik

a. Memberikan fasilitas yang dapat mendukung terciptanya aktifitas komunikasi antar mahasiswa. Terutama memberikan ruang dan waktu yang lebih untuk mahasiswa melakukan diskusi tentang perkuliahan, sehingga tercipta komunikasi yang lebih baik di antara mahasiswa.

b. Memberikan akses yang lebih mudah kepada mahasiswa untuk bisa bertemu dan berkonsultasi dengan dosen, terutama dalam hal pembahasan perkuliahan. Sehingga dapat terwujud komunikasi yang efektif dan terbuka yang memungkinkan terjadinya diskusi, sharing tentang masalah perkuliahan.

3. Bagi Peneliti

Peneliti selanjutnya yang berminat untuk meneliti mengenai hubungan antara komunikasi interpersonal mahasiswa dengan dosen dan antar mahasiswa terhadap motivasi belajar, khususnya di Jurusan Ortotik Prostetik Poltekkes Surakarta, disarankan untuk mempertimbangkan faktor dan variabel yang lain.

\section{DAFTAR RUJUKAN}

Afzal, H, dkk. 2010. A Study of University Students' Motivation and Its Relationship with Their
Academic Performance.

International Journal of Business and Management, 5(4), 80-89.

Agustina N. (2011). Media dan Pembelajaran.Palembang:

Universitas Sriwijaya

Brophy, J. 2004. Motivating Students to Learning, Lawrence Erlbaum Associates. New Jersey.

DeVito, J A. 2007. The Interpersonal Communication Book.edisi 11. Pearson Educations, Inc.

Hamalik, O. 2009. Proses Belajar Mengajar. Bandung: Bumi Aksara

Handoko, M. 1992. Motivasi daya penggerak tingkah laku. Jakarta: Rineka cipta

Liliweri, A. 2003. Makna Budaya Dalam Komunikasi Antar Budaya. Yogyakarta: Pustaka Pelajar.

Mulyana, D. 2006. Metode penelitian Kualitatif. Bandung: Remaja Rosdakarya.

Muhammad, A. 2005. Komunikasi Organisasi. Jakarta: Bumi Aksara.

Nurhidayah, A.M.S. 2013. Peran Komunikasi Interpersonal Wali Kelas Terhadap Motivasi Belajar Siswa Kelas Vidi Mi Darul Huda Ngaglik Sleman. Skripsi. Yogyakarta: Fakultas ilmu Tarbiyah dan Keguruan, Universitas Islam Negeri Sunan Kalijaga Yogyakarta.

Pintrich, P. R. 2003. A motivational science perspective on the role of student motivation in learning and teaching contexts. Journal of educational Psychology, 95, 667686.

Prasetya, A. 2010. Hubungan Antara Komunikasi Edukatif Dengan Motivasi Belajar Mahasiswa. 
Skripsi. Semarang: Universitas Diponegoro.

Rakhmat, J. 2005. Psikologi Komunikasi (edisi revisi). Bandung: Remaja Rosdakarya.

Rozaq, F. 2012. Korelasi Komunikasi Interpersonal Guru Dan Siswa Terhadap Keaktifan Belajar Siswa Kelas XI Program Keahlian Teknik Otomotif di SMK Muhammadiyah 4 Klaten Tengah Tahun Ajaran 2012/2013. Skripsi. Yogyakarta: Fakultas Teknik, Universitas Negeri Yogyakarta.

Rusyan, A.T. 1993. Proses Belajar Mengajar yang Efektif Tingkat Pendidikan Dasar. Bandung: Bina Budaya.

Ryan, R.M., \& Deci, E.L. 2000. Intrinsic and extrinsic motivations: Classic definitions and new directions. Contemporary Educational Psychology, 25, 54-67

Sagala, S. 2009. Konsep dan Makna Pembelajaran. Bandung: CV. Alfabeta

Santrock, J W. 2008. Psikologi Pendidikan (edisi kedua). Jakarta: Kencana Prenada Media Group.

Sardiman, A.M. 2011. Interaksi dan Motivasi Belajar Mengajar. Jakarta: Rajawali.

Sendjaja, D. 2004. Pengantar ilmu komunikasi. Jakarta: PT. Raja Grafindo Persada.

Sunaryo. 2004. Psikologi Untuk Keperawatan. Jakarta: EGC.

Suprijono, A. 2009. Cooperative Learning Teori Dan Aplikasi Paikem. Yogyakarta: Pustaka Pelajar.

Suranto, A.W 2011. Komunikasi interpersonal. Yogyakarta: Graha Ilmu.
Surya, M. (2003). Psikologi Pembelajaran dan Pengajaran. Bandung: Yayasan Bhakti Winaya

Uno, H.B. 2010. Teori Motivasi \& Pengukurannya Analiasis Dibidang Pendidikan (1rd ed). Jakarta: Bumi Aksara

Wahyudi, D. 2011. Efektifitas Komunikasi Interpersonal Dosen Pembimbing Akademik Dalam Peningkatan Motivasi Belajar Mahasiswa. Tesis. Bengkulu: Fakultas Ilmu Sosial Dan Politik, Universitas Bengkulu.

Widjaja, H.A.W. 2000. Ilmu Komunikasi Pengantar Studi, Edisi Revisi. Jakarta: PT Rineka Cipta.

Widyawati, E. 2009. Pengaruh Konsep Diri Terhadap Motivasi Belajar Mahasiswa. Skripsi. Jakarta: Fakultas Ekonomi, Universitas Gunadarma. 